\title{
Breve análise de dispositivos da Constituição da República Federativa do Brasil de 1988
}

\author{
Brief analysis of articles of the 1988 Constitution of the Federative \\ Republic of Brazil
}

\author{
Tarsis Barreto Oliveira \\ Herisberto e Silva Furtado Caldas ${ }^{2}$ \\ Paulo Vitor Nunes da Silva ${ }^{3}$
}

\begin{abstract}
RESUMO
Visa o presente artigo apresentar à comunidade acadêmica um contributo no debate sobre a Constituição da República Federativa do Brasil de 1988. E assim o faz rememorando aspectos de sua promulgação, trazendo ao cenário jurídico um aspecto pouco debatido na doutrina, consistente na existência, expressamente declarada por um importante Deputado Constituinte, de artigos que não foram votados pela Assembleia Nacional Constituinte no período de 19871988, a saber: Artigo $2^{\circ}$, Artigo 166, §3, Inciso II, alíneas "a", "b" e "c", todos da Magna Carta de 88. Argumenta-se acerca das implicações teóricas e práticas da referida inclusão à sorrelfa dos referidos artigos. Debate-se, ainda, sobre a polêmica doutrinária referente à (in)existência de autonomia reconhecida aos Municípios, sob a ótica do Federalismo brasileiro de terceiro grau. Conclui-se, com amparo na doutrina, que os Municípios apresentam um "status especial", de modo que continuam, ainda, a ser divisão do Estado. Igualmente, discute-se sobre a possibilidade de Propostas de Emendas à Constituição por meio de participação popular, apesar da omissão constitucional do Art. $61, \S 2^{\circ}$, da CRFB. Por fim, tratou-se da necessidade de uma redefinição das funções do Supremo Tribunal Federal, dentro do prisma da jurisdição constitucional e do papel do Supremo com guardião da Constituição.
\end{abstract}

\section{PALAVRAS-CHAVE:}

Constituição Federal, normas quelônias, autonomia municipal, jurisdição constitucional.

\begin{abstract}
The aim of this article is to present to the academic community a contribution to the debate on the 1988 Constitution of the Federative Republic of Brazil. And it does so by recalling aspects of its promulgation, bringing to the legal scene an aspect little debated in the doctrine, consistent in the existence, expressly declared by an important Constituent Deputy, of articles that were not voted on by the National Constituent Assembly in the period of 1987-1988, namely: Article 2, Article 166, Paragraph 3, Item II, points "a", "b" and "c ", all of them from the Magna Carta

\footnotetext{
${ }^{1}$ Doutor e Mestre em Direito pela UFBA. Professor Adjunto de Direito da UFT e UNITINS. Professor do Mestrado em Prestação Jurisdicional e Direitos Humanos da UFT/ESMAT. Membro do Comité International des Pénalistes Francophones e da Association Internationale de Droit Pénal. E-mail: tarsisbarreto@uft.edu.br.

${ }^{2}$ Mestre em Prestação Jurisdicional de Direitos Humanos pela Universidade Federal do Tocantins - UFT e Escola Superior da Magistratura do Tocantins - ESMAT, Especialista em direito Constitucional pela Escola Superior da Magistratura do Estado do Ceará - ESMEC. Juiz de Direito. E-mail: hsbtfurtado@uol.com.br.

${ }^{3}$ Bacharel em Direito pela Faculdade Católica Dom Orione. Assessor Jurídico no Ministério Público do Estado do Tocantins. E-mail: paulovitor1995@outlook.com.
} 
of 88. It argues about the theoretical and practical implications of the forced inclusion of those articles. There is also a debate on the doctrinal controversy regarding the (in)existence of autonomy recognized by the Municipalities, from the perspective of third-level Brazilian Federalism. It is concluded, supported by the doctrine, that the Municipalities have a "special status", so that they still remain a division of the State. Likewise, it is discussed about the possibility of Proposed Amendments to the Constitution through popular participation, despite the constitutional omission of Art. $61, \S 2^{\circ}$, of the CRFB. Finally, there was a need to redefine the functions of the Supreme Federal Court, within the framework of constitutional jurisdiction and the role played by the Supreme as the guardian of the Constitution.

\section{KEYWORDS:}

Federal Constitution, chelonian rules, municipal autonomy, constitutional jurisdiction.

\section{INTRODUÇÃO}

Em data de 5 de outubro de 1988, como é cediço, foi promulgada a oitava constituição da República Federativa do Brasil, denominada por Ulysses Guimarães como Constituição Cidadã.

O processo legislativo de formação do texto constitucional inicia-se, formalmente, com a Emenda Constitucional (EC) $\mathrm{n}^{\mathrm{o}} 26$, de 27 de novembro de 1985, a qual convocava a Assembleia Nacional Constituinte (ANC) para elaboração na nova Constituição, cujos trabalhos se iniciaram em fevereiro de 1987 e perduraram até a entrega do novo Livro ao povo brasileiro.

É neste cenário pré-constitucional que os dispositivos foram discutidos e votados pelos integrantes da Assembleia, como forma de obedecer ao processo de formação da Carta Magna.

Ressalte-se, porém, que, em relação a dois artigos da Constituição Federal de 1988, tal regramento não foi observado. Este é o primeiro capítulo do presente trabalho, versando sobre o Artigo $2^{\circ}$ e Artigo 166, §3º Inciso II, alíneas “a", "b” e “c", introduzidos de forma não democrática, como se verá logo mais. 
A discussão acerca dos outros três temas não se referem ao aspecto formal de elaboração da lei, mas sim ao conteúdo material introduzido na Carta Política, que permanecem ao longo destes mais de 30 anos de sua promulgação, sendo eles:

I. A polêmica jurídica relacionada à (in)existência de autonomia dos Municípios, sob a ótica do federalismo;

II. A (im)possibilidade de participação popular quanto às emendas constitucionais, em especial acerca do choque entre titular e portador do poder constituinte;

III. A necessidade de se redefinir as funções do Supremo Tribunal Federal, com abordagem na questão relacionada à jurisdição constitucional.

Nesse passo, o trabalho se desenvolve com estes objetivos: apontar quatro pontos controvertidos da Constituição de 1988, além de fomentar o debate constitucional acerca de tais temas.

\section{NORMAS CONSTITUCIONAIS QUELÔNIAS (ARTIGOS NÃO VOTADOS, MAS PROMULGADOS)}

Há alguns artigos da Constituição Federal de 1988 que não foram sequer apreciados em plenário da Assembleia Nacional Constituinte de 1987/1988.

Esta assombrosa constatação veio a lume na Edição de 05 de outubro de 2003 do Jornal O Globo ${ }^{4}$, em edição comemorativa dos 15 anos da Constituição, na entrevista dada pelo então Ministro do STF Nelson Jobim, que fora à época da ANC Deputado Federal Constituinte pelo Estado do Rio Grande do Sul, à repórter Lydia Medeiros.

No referido colóquio, o jurista e ex-deputado constituinte afirmara que dois artigos da

\footnotetext{
${ }^{4}$ Eis a matéria da capa: "Artigos da Constituição de 88 entraram em vigor sem votação" disponível em: <http://memoria.oglobo.globo.com/jornalismo/edicoes-especiais/sem-votaccedilatildeo-9938719>. Acesso em 20 de outubro de 2017.
} 
Constituição entraram em plenário sem que os tenham votado os representantes do povo.

Segundo Jobim, tal fato não houvera sido anteriormente aberto ao público em razão de ter havido uma espécie de acordo entre o Presidente da ANC Ulysses Guimarães e o próprio Nelson Jobim, pelo qual este só estaria autorizado a revelar este segredo passados quinze anos da Constituição. Inclusive, na referida entrevista, o ex-deputado constituinte chegou a anunciar que começara a escrever um livro sobre os trabalhos da ANC. No entanto, tal livro nunca chegou a ser publicado.

À época, revelou que o atual art. $2^{\circ 5}$, que trata da divisão de poderes, foi incluído de última hora, pois, quando da redação final pela comissão responsável pela correção gramatical do texto para a votação final e simbólica, notou-se que referido artigo, cujo conteúdo é essencial às modernas constituições (isto é, pós-revolução francesa), não havia sido incluído, de modo que o Ex-Deputado dissera: (2003, p. 1) "vamos incluir, não tem outro jeito".

A existência do citado dispositivo é de suma importância, na medida em que, além de contrastar com o pensamento absolutista, exteriorizado, principalmente, por meio da célebre frase de Luís XIV: “L'État c'est moi” (o Estado sou eu), relega a segundo plano a teoria dos freios e contrapesos (checks and balances).

Ressalte-se, todavia, que sua ausência não traria prejuízos de interpretação acerca de sua existência implícita, uma vez que, ao tratar da Organização dos Poderes, nossa Carta Magna, em seu título IV, acaba por discorrer sobre a organização dos Poderes, ou seja, passa a tratar das figuras do Poder Legislativo (art. 44-75), do Poder Executivo (art. 76-91) e Poder Judiciário (art. 92-126).

A crítica ao citado dispositivo não repousa no fato de sua existência concreta, mas da forma escolhida para sua colocação ao texto constitucional, uma vez que introduzido sem o necessário debate democrático, sem o respeito ao Poder Constituinte Originário e sem obediência à formalidade constitucional,

O segundo artigo, o qual Nelson Jobim, quando da entrevista, dissera que só revelaria em livro, nunca foi por este desvelado.

\footnotetext{
${ }^{5}$ Art. $2^{\circ}$ São Poderes da União, independentes e harmônicos entre si, o Legislativo, o Executivo e o Judiciário.
} 
Não obstante, a despeito do silêncio do ex-Deputado e ex-Ministro do Supremo, em importante pesquisa documental, Adriano Benayon e Pedro Antônio Dourado de Resende publicaram o artigo intitulado “Anatomia de uma fraude à Constituição”, em agosto de 2006, no departamento de ciência da computação da Universidade Nacional de Brasília ${ }^{6}$, pelo qual os autores identificaram como segundo "artigo quelônio" o Artigo 166, §3º , Inciso II, alíneas "a", "b" e "cc" (inserido no Título VI - Da Tributação e do Orçamento, Capítulo II - das Finanças Públicas, Seção II - Dos Orçamentos) ${ }^{7}$, que incluíram exceções para a indicação de recursos em emendas parlamentares a projetos.

Há que se ressaltar a metodologia empregada pelos pesquisadores.

Utilizou-se de pesquisas empíricas documentais dos registros materiais da ANC de $87 / 88^{8}$. Contam os citados autores que o artigo foi inserido no momento da discussão final do texto da Constituição pela ANC, pelo qual se materializou em decisão apenas simbólica de aprovação por parte dos parlamentares-constituintes reunidos, quando já não se poderia acrescentar outras disposições, nos termos do art. 29 do Regimento Interno da ANC (Resolução $\mathrm{n}^{\circ} 2$ de 1987 da ANC) $)^{9}$.

Se há razões, dentro da teoria constitucional, ainda que se possa negá-las, para a instituição do $\operatorname{artigo~} 2^{\circ}$ no bojo da Constituição sem que se passasse por votação prévia, motivos no mínimo questionáveis pairam sob a inserção do art. 166, $\S 3^{\circ}$, Inciso II, alíneas $a, b$ e $c$ da Constituição Cidadã.

Inicialmente, comentamos sucintamente o art. 166. Trata o caput desse artigo do

\footnotetext{
${ }^{6}$ Disponível em: <http://cic.unb.br/ pedro/trabs/fraudeac_files/fraudeac.pdf >. Acesso em 20 de outubro de 2017.

${ }^{7}$ Art. 166. Os projetos de lei relativos ao plano plurianual, às diretrizes orçamentárias, ao orçamento anual e aos créditos adicionais serão apreciados pelas duas Casas do Congresso Nacional, na forma do regimento comum. [...] $\S 3^{\circ}$ As emendas ao projeto de lei do orçamento anual ou aos projetos que o modifiquem somente podem ser aprovadas caso: [...] II - indiquem os recursos necessários, admitidos apenas os provenientes de anulação de despesa, excluídas as que incidam sobre: a) dotações para pessoal e seus encargos; b) serviço da dívida; c) transferências tributárias constitucionais para Estados, Municípios e Distrito Federal;

8 Destacamos, dentre os vários "elementos tipificadores" (BENAYON e RESENDE, 2006, p. 09/10): a ausência de manifestação, no requerimento de fusão de assinatura ou qualquer outra expressão, do autor da proposta de Emenda citada para fusão; ausência de rubrica de dos autores das propostas de Emendas citadas para fusão; a inexistência, no texto que fora submetido ao segundo turno da constituinte, da previsão do citado artigo; declarações do então Ministro Nelson Jobim e de outros parlamentares admitindo, indiretamente, a irregularidade, dentre outras constatações do trabalho.

${ }^{9}$ Art. 29. Recebido o parecer da Comissão, este será publicado no Diário da Assembleia Nacional Constituinte e em avulsos, sendo a matéria, dentro de 48 (quarenta e oito) horas, Incluída em Ordem do Dia, para discussão em segundo turno, nela podendo permanecer até 15 (quinze) dias, vedada a apresentação de novas emendas, salvo as supressivas e as destinadas a sanar omissões, erros ou contradições, ou de redação para correção de linguagem.
} 
processo legislativo de Projetos de Lei relativos ao Direito Financeiro, como do Projeto de Lei Orçamentária (PLOA), o Projeto de Lei Diretrizes Orçamentárias (PLDO), o Projeto de Lei Plurianual (PLPA) e sobre créditos orçamentários adicionais.

Especificamente, o $\S 2^{\circ}$ refere-se à possibilidade de emendas por parte dos congressistas ao PLOA (cuja iniciativa é privativa do Chefe do Executivo Federal).

No referido artigo, e aqui se adentra ao artigo quelônio, vedam-se quaisquer tipos de emendas por parte dos congressistas relativas a: alínea a) dotações para pessoal e seus encargos; alínea b) serviço da dívida; e alínea c) transferências tributárias constitucionais para Estados, Municípios e Distrito Federal.

Das três vedações de emendas parlamentares ao PLOA, a primeira (alínea a) se refere ao pagamento de servidores públicos, cuja despesa é certa e recorrente na Administração, o que poderia ser justificável ${ }^{10}$, pragmaticamente. Igual obrigatoriedade ocorreria com a terceira previsão (alínea c), que veda alterações do valor repassado aos demais entes federativos, isto é, a regra das transferências constitucionais compulsórias de receitas tributárias.

Há dúvidas, no entanto, dos motivos para a inclusão prevista na alínea "b", cujo conteúdo refere-se à proibição de Emendas ao PLOA referentes ao pagamento da dívida pública.

Com a referida proibição, o Presidente da República (único legitimado) está livre para definir o que o Estado terá de pagar aos credores da dívida pública brasileira e dos seus juros, sem que ocorra qualquer tipo de controle de legitimidade por parte do povo - cujo freio deveria ser exercido por meio de seus representantes eleitos, já que impossível emendas.

Identificamos, aqui, três consequências da inserção do referido artigo, que serão no decorrer do trabalho analisadas: a) o fato, em si, de não ter sido debatido democraticamente (aspecto formal-democrático); e, por fim, b) sobre a própria essência por trás da regra constitucional (aspecto material).

Inicialmente, no que se refere especificamente à inserção do Artigo 166, §3º , Inciso II, alíneas $a, b$ e $c$, feito à sorrelfa e à socapa, como testificou a referência supracomentada e

\footnotetext{
${ }^{10}$ vide art. $37, \mathrm{X}, \mathrm{da} \mathrm{CF} / 88$.
} 
indicou em entrevista o ex-Deputado Federal Constituinte Nelson Jobim, trata-se de medida tirânica por excelência.

Ao menos desde Jürgen Habermas sabe-se que a relação entre Direito e Democracia é imbricada. Conforme pudemos comentar em certa oportunidade (SILVA, 2015, p. 56), com base na leitura do mestre alemão: "A legitimidade de uma decisão política tomada dentro do uso da razão pública está menos na adesão de vontade dos participantes ao argumento vencedor do que no procedimento adotado.

Tal fraude coloca em questionamento a pecha de Constituição Cidadã propalada por Ulysses Guimarães quando da promulgação da Constituição.

Sob o aspecto material, a regra constitucional se mostrou amplamente protetiva aos credores da dívida pública, conforme observa Fernando Facury Scaff ${ }^{11}$. O fato de o analisado artigo impedir qualquer tipo de emenda, por parte do Legislativo, no montante determinado pelo Presidente da República a ser pago aos credores da dívida (instituições financeiras nacionais e internacionais) acaba por deslegitimar negociações privatistas entre o Presidente e os credores da dívida.

Tais previsões, ainda conforme observa Scaff, são prejudiciais ao modelo de Constituição programática a que a carta magna de 1988 se propôs a ser, já que:

\section{A dívida pública, tal qual organizada no sistema orçamentário brasileiro, atrasa o ritmo de ampliação dos direitos fundamentais no Brasil, em especial os que necessitam de maior gasto público, como os que devem ser realizados com saúde, educação, mobilidade urbana, moradia e outros que tais.}

É uma verdadeira caução perpétua para o pagamento da dívida, instituída à sorrelfa no referido art. 166, $\S 3^{\circ}$, inc. II, do texto que viria a ser aprovado da Constituição de 1988.

De fato, apresenta-se como um bom negócio ser credor do Estado Brasileiro.

A partir destas e outras constatações sobre a tessitura jurídica do direito financeiro/orçamentário no Brasil é que surgiu com Bercovici e Massoneto (2006) a clássica obra do Direito Financeiro Constitucional A Constituição Dirigente Invertida, pelo qual os

\footnotetext{
${ }^{11}$ Disponível em: <http://www.conjur.com.br/2014-set-09/contas-vista-divida-publica-atrasa-ampliacao-direitosfundamentais> acessado em 06 de outubro de 2017>. Acesso em 20 de outubro de 2017.
} 
autores proclamam, em síntese, que (BERCOVICI e MASSONETO, 2006, p. 71/72):

\begin{abstract}
A implementação da ordem econômica e da ordem social da Constituição de 1988 ficaram restritas, assim, às sobras orçamentárias e financeiras do Estado. A constituição financeira de 1988 foi, deste modo, "blindada". A Lei de Responsabilidade Fiscal apenas complementa este processo. [...] a constituição dirigente invertida, isto é, a constituição dirigente das políticas neoliberais de ajuste fiscal é vista como algo positivo para a credibilidade e a confiança do país junto ao sistema financeiro internacional. Esta, a constituição dirigente invertida, é a verdadeira constituição dirigente, que vincula toda a política do Estado brasileiro à tutela estatal da renda financeira do capital, à garantia da acumulação de riqueza privada.
\end{abstract}

O modelo de Constituição Dirigente Invertida, por meio do qual o Estado limita sua ação social a um apêndice das sobras orçamentárias certamente prejudica o modelo programático da Constituição dirigente, e a referida proibição esvazia todo o plexo de direitos sociais.

\title{
3. A (IN)EXISTÊNCIA DE AUTONOMIA DOS MUNICÍPIOS
}

Fundada controvérsia doutrinária reside no status constitucional efetivo do Município a partir dos termos da Constituição Federal de 1988. Tal celeuma se dá em saber se o ente local faz parte ou não da tessitura político-organizacional federal brasileira ao lado dos Estados, Distrito Federal e União.

Verificou-se no decorrer da história constitucional brasileira, a partir de Albuquerque e Vilaça (2003), que ao Município se reconhecia apenas o acento de unidades políticoadministrativas, dentro do federalismo brasileiro, vindo somente com a Constituição da República de 1988 o seu status constitucional ao lado da União, Estados e Distrito Federal.

Conforme observou Branco (2008), Municípios existem desde 1532 no Brasil ${ }^{12}$, os quais representaram, durante o tempo de colônia, a parte material do poder português.

\footnotetext{
12 O primeiro Município brasileiro, como se sabe, é o Município de São Vicente, localizado no Estado de São Paulo.
} 
A primeira Constituição brasileira, a de $1824^{13}$, instituiu as Câmaras como entidade máxima representativa dos interesses locais (Cidades e Vilas).

A Constituição republicana de 1891 inovou, formalmente, ao reconhecer autonomia ao ente Municipal ${ }^{14}$; no entanto, conforme esclarece Branco (2008, p. 198), tal autonomia ficara no plano semântico, na medida em que, em razão das particularidades sociais da época (coronelismo, clientelismo e poder nas mãos dos grandes proprietários de terras), "os Municípios, [...] neste cenário, representavam extensões do poder estatal”.

Por sua vez, a Constituição de 1934 previu, como inovação, competência e capacidade tributária aos Municípios ${ }^{15}$, representando avanço na autonomia dada aos entes locais.

Como retrocesso a esta autonomia municipal, a Constituição do Estado-Novo (1937) estabeleceu que os prefeitos passariam a ser nomeados pelos governadores dos EstadosMembros, não existindo câmaras legislativas como na época do Brasil império, no que, bem observou Hely Lopes Meirelles (2006, p. 41), passaram a ter os Municípios menos autonomia que na época monárquica brasileira, tal o nível de concentração de poder na figura de Getúlio Vargas e de seus representantes nos Executivos municipais e estaduais.

Com o processo de redemocratização da Constituição de 1946, retornou-se ao reconhecimento de autonomia, nos moldes pré-Estado Novo.

A seu turno, a Constituição de 1967 (com a Emenda Constitucional nº 1, de 1969), recrudesceu os avanços obtidos rumo à autonomia municipal, a centralizar o poder em prol do regime militar. Apesar de manter-lhes, formalmente, a autonomia, limitou-a, ao estabelecer a nomeação, pela junta militar, de prefeitos nas cidades consideradas de interesse nacional, como capitais e grandes cidades.

\footnotetext{
${ }^{13}$ Art. 167. Em todas as Cidades, e Villas ora existentes, e nas mais, que para o futuro se crearem haverá Camaras, ás quaes compete o Governo economico, e municipal das mesmas Cidades, e Villas.

[...] Art. 169. O exercicio de suas funcções municipaes, formação das suas Posturas policiaes, applicação das suas rendas, e todas as suas particulares, e uteis attribuições, serão decretadas por uma Lei regulamentar.

${ }^{14}$ Art. 68 - Os Estados organizar-se-ão de forma que fique assegurada a autonomia dos Municípios em tudo quanto respeite ao seu peculiar interesse.

${ }^{15}$ Art. 13 - Os Municípios serão organizados de forma que lhes fique assegurada a autonomia em tudo quanto respeite ao seu peculiar interesse; e especialmente: [...] II - a decretação dos seus impostos e taxas, a arrecadação e aplicação das suas rendas;
} 
Por fim, o grande diploma a reconhecer autonomia ao ente municipal é a Constituição Federal de 1988, a qual reconhece que a República Federativa do Brasil é formada pela união indissolúvel dos Estados, Distrito Federal e Municípios (art. $1^{\circ}$, caput), bem como assegurando que a organização político-administrativa da República compreende a União, os Estados, o Distrito Federal e os Municípios, todos autônomos, nos termos da CF (art. 18, caput).

Não obstante tal aparente reconhecimento, a doutrina diverge sobre o real posicionamento da administração Municipal e sobre os limites da reconhecida autonomia. O simples fato de se reconhecer autonomia ao Município não importa, necessariamente, em entabulá-lo como ente federativo, visto que o Ministério Público também é autônomo, assim como uma administração pública indireta (a exemplo da autarquia INSS).

José Afonso da Silva (2009, p. 640), reconhecendo ter a Constituição integrado o Município como ente federativo, pondera que tal inclusão teria, necessariamente, que "vir acompanhada de consequências", o que, em alguns casos, a Constituição deixou de prevê-las.

Nessa esteira, deve-se interpretar a Constituição em seu todo, como um sistema autopoiético, autorreferente (LUNMANN), não apenas isoladamente, mas como um capítulo de um livro (DWORKIN), sob pena de perda da sua força normativa, que, se é assegurada observando-lhe a vontade (HESSE), tanto mais o é quando a interpretam como um sistema.

Outras tantas, no entanto, são as incongruências que nos impedem de definirmos o Município como ente autônomo na federação brasileira (em compilação, a Constituição se valeu por 11 vezes da expressão, tanto no plural, quanto no singular, unidade federada e unidade da federação, e em nenhuma delas referiu-se ao Município, apenas aos Estados e ao Distrito

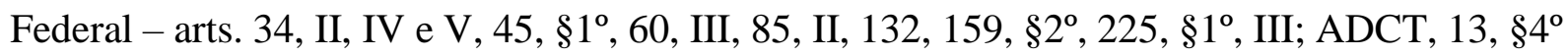
e $32, \S 9^{\circ}$, - SILVA, 2009, p. 640).

Nem se argumente, como o faz Branco (2015), que houvera apenas omissão pragmática (em razão do número de municípios) do poder constituinte originário. Trata-se, a nosso viso, de omissão intencional da Assembleia Nacional Constituinte, na medida em que falece interesse legítimo de se verem representados Municípios, ou grupos de Municípios, no Ágora nacional, restando aos Municípios apenas representantes em âmbito local, sítio próprio para discussões de interesses menores que não transcendam à esfera de um Estado-Membro. 
Ora, tal não é a ausência de essência federativa (CASTRO, p. 28) aos Municípios que não se lhes é assegurada, mesmo, a possibilidade de interferir diretamente no processo legislativo do diploma que lhes assegurou a própria autonomia. Ou, ainda, caso se queira ir mais além, até lhes foi assegurada tal participação, mas o foi por meio de ente interposto, de um representante seu - Assembleias Legislativas Estaduais.

Por fim, serviços públicos, em tese, caracterizadores da autonomia de um ente federado não se repetiram nos Municípios. Assim se dá com a inexistência de agentes de polícia municipais, Poder Judiciário local e impossibilidade de se criarem Tribunal de Contas municipais.

Outras atividades poderiam revelar autonomia aos entes municipais, como: a) a extensão de legitimidade material aos vereadores (cuja aplicação se dá apenas aos Deputados Federais, Senadores e Deputados Estaduais); b) a possibilidade de fiscalização concentrada de constitucionalidade, via ação direta ao STF (ADI, ADO e ADC), o que, do contrário, se imputou ao Tribunal de Justiça dos Estados, tal controle; ou, ainda, c) a possibilidade de o próprio Município estabelecer regiões metropolitanas, aglomerações urbanas e microrregiões, sem ter que se submeter à Lei Complementar estadual, a quem compete tal redesenho administrativo dos Municípios (haveria violação maior à pretensa autonomia reconhecida aos Municípios do que lhes submeter a outro ente federado para estabelecimento de interesses administrativos locais?); ou, por fim,

d) a possibilidade de, por Lei Complementar (art. 22, parágrafo único) Federal, delegarse assuntos específicos de competência da União aos Municípios, fato este só admitido aos Estados-Membros.

Não se deve olvidar, portanto, o fato de o Município, dentro da tessitura constitucional brasileira, não fazer parte da unidade federada. Daí a conclusão de José Nilo de Castro (2010, p. 31): "De nada adiante dizer, como está escrito no art. $1^{\circ}$ da Constituição Federal, que o Município é ente componente da Federação, se, pesquisando as demais regras constitucionais, a assertiva não mais avança, tal a desconformidade sistemática, no particular”.

Mas, então, que seria o Município, se não lhe é possível reconhecer o status de ente federado? 
Conjugando as lições de José Afonso da Silva (2005) e José Nilo de Castro (2010), é possível afirmar que se está diante de um nominalismo federativo (CASTRO, p. 32), revelandose que o Município, ainda, continua a ser divisão do Estado (SILVA, 2005).

E isso, a bem da verdade, não lhe tira a importância dentro da moldura constitucionaladministrativa, já que é o ente público, por excelência, administrador dos interesses mais particulares, isto é, locais, da coletividade, apenas impedindo concluir fazerem parte do pacto federativo, tal como classicamente concebeu a doutrina.

\section{PARTICIPAÇÃO POPULAR E EMENDAS À CONSTITUIÇÃO - CHOQUE ENTRE TITULAR E PORTADOR DO PODER CONSTITUINTE}

A Constituição, apesar de dizer que todo o poder emana do povo (Parágrafo único do art. $1^{\circ}$ ) e que a soberania popular se exerceria por meio de iniciativa popular (art. 14, inc. III), prevê apenas a iniciativa popular para Projetos de Leis ordinárias e complementares, silenciando sobre Emendas à Constituição.

Assim preceitua o art. $61, \S 2^{\circ}$ tratando da iniciativa de Projetos de Leis no Congresso Nacional (redação sem alterações desde a promulgação): “A iniciativa popular pode ser exercida pela apresentação à Câmara dos Deputados de projeto de lei subscrito por, no mínimo, um por cento do eleitorado nacional, distribuído pelo menos por cinco Estados, com não menos de três décimos por cento dos eleitores de cada um deles".

A título informativo, nestes mais de 30 anos da Constituição, foram apenas quatro as Leis aprovadas a partir da sistemática do art. 61, §2 , a saber: Lei 8.930/1994 (que incluiu o homicídio qualificado no rol dos crimes hediondos; Lei 9.840/1999 (Lei que proíbe a compra de votos); Lei 11.124/2005 (Lei que determinou a criação do Fundo Nacional de Habitação de Interesse Social para pessoas de baixa renda) e a Lei Complementar $n^{\circ}$ 135/2010 (Lei da Ficha Limpa, determinando inelegibilidade por 8 anos daquele que foi condenado em segunda instância em processo criminal, dando outras providências. 
A par das considerações das diferentes formas de exercê-la, a escolha da ANC de conferir ao povo a iniciativa popular apenas para apresentação de Projetos de Leis Ordinárias e Complementares, deixando de permitir expressamente tal instrumento para Emendas à Constituição, fere a teoria do Poder Constituinte. Com efeito, conforme se ressaltou neste trabalho, o titular do Poder Constituinte, sabe-se desde Syeiès (1988), é o povo.

Não obstante ser o titular, o povo é o titular passivo do Poder Constituinte, cabendo a alguns da comunidade a representação destes titulares, isto é, são os portadores do Poder Constituinte, conforme leciona Ferreira Filho (2014, p. 232).

Nesse sentido, aqui se encerrou uma constatação contraditória. Para garantir a legitimidade desta outorga, a estes portadores coube seguir com a vontade do povo, o titular efetivo e permanente do Poder Constituinte Originário, que, por sua vez, retiraram do titular o poder de deliberar sobre a iniciativa de Emendas à Constituição.

Ao omitir-se a respeito da legitimidade de iniciativa em PEC ao povo, no momento em que se deveria ter como expressão máxima da democracia representativa, os membros da ANC de 87/88 se afastaram do interesse dos titulares do Poder Constituinte Originário - isto é, o povo, do qual receberam mandato.

A solução para tal contradição, portanto, seria uma interpretação sistemática dos preceitos Constitucionais, conjugando o art. $1^{\circ}$, Parágrafo Único, com o Art. 14, inc. III, conforme o magistério de parte da doutrina, como José Afonso da Silva (2005), Daniel Sarmento e Cláudio Pereira de Souza Neto (2012), para os quais deve-se permitir também a iniciativa popular em se tratando de iniciativa em Propostas de Emenda à Constituição.

\section{JURISDIÇÃO CONSTITUCIONAL: A NECESSÁRIA REDEFINIÇÃO DAS FUNÇÕES DO SUPREMO TRIBUNAL FEDERAL}


Outro ponto a merecer reflexão, nesses pouco mais de 30 anos da Constituição de 1988, é o papel dado ao Supremo Tribunal Federal (STF), especialmente diante da ideia de Jurisdição Constitucional.

Inicialmente, cabe verificar a opção tomada pela ANC de 87/88 de manter os nomeados pelo antigo regime militar como sendo membros efetivos da excelsa corte ${ }^{1617}$. Trata-se de exemplo claro de opção de transição que, a bem da verdade, prejudicou o processo interpretativo da Nova Constituição.

Ora, se o objetivo era romper as amarras deixadas pelo período de ditadura militar, certamente que manter na mais alta corte constitucional magistrados nomeados pelo antigo regime não facilitou este trabalho.

Como bem observou Barroso (1999, p. 13):

\begin{abstract}
O constituinte de 1988 tomou, sem maior debate político, a decisão grave de manter como integrantes do STF todos os Ministros que haviam sido investidos no Tribunal pelos governos anteriores. Vale dizer: sem embargo da inegável virtude pessoal e intelectual de muitos dos juízes que lá tinham assento, a corte constitucional brasileira, encarregada de interpretar a nova Carta, era composta de juristas cuja nomeação era lançada a crédito do regime militar.
\end{abstract}

A jurisprudência retrospectiva aplicada por parte do STF, como anotou Barroso, é argutamente conceituada por Barbosa Moreira (2005, p. 768) que também identificou tal problemática com a corte de transição:

\begin{abstract}
Põe-se ênfase nas semelhanças, corre-se um véu sobre as diferenças e conclui-se que, à luz daquelas, e a despeito destas, a disciplina da matéria, afinal de contas, mudou pouco, se é que na verdade mudou. É um tipo de interpretação em que o olhar do intérprete dirige-se antes ao passado que ao presente, e a imagem que ele capta é menos a representação da realidade que uma sombra fantasmagórica.
\end{abstract}

Deve-se levar em conta a ausência de legitimidade da escolha - a escudar a decisão, a sua base política (porque a nomeação de um Ministro do STF é sempre um ato político, permeado por regras jurídicas), já que esta certamente fora maculada, já que não se pôde ter

\footnotetext{
${ }^{16}$ Essa afirmação pode ser verificada no sítio do $\quad$ STF em $\langle$ http://www.stf.jus.br/portal/ministro/ministro.asp?presidente=\&periodo=stf $>$

17 A título argumentativo, em 1964, quando da tomada de poder pelo regime militar, três ministros foram removidos por serem considerados "de esquerda", os Ministros Hermes Lima, Victor Nunes Leal e Evandro Lins e Silva, restaram da composição original: Vilas Boas, Lafayette de Andrada, Ribeiro da Costa (Presidente), Candido Motta Filho (Vice-Presidente), Luiz Gallotti, Gonçalves de Oliveira. Ministros Aliomar Baleeiro, Oswaldo Trigueiro, Prado Kelly, Pedro Chaves, Adalicio Nogueira, Carlos Medeiros e Hahnemann Guimarães.
} 
participação popular naqueles que foram nomeados pelo regime militar durante o período de 1964 a 1985, ainda que indireta, como houvera antes do regime e posteriormente com a nova Constituição.

Outro aspecto que comprometeu o pleno exercício da jurisdição por parte do STF foi o grandioso número de atribuições que a Carta lhe atribuíra.

A despeito de a Constituição delegar o papel de seu guardião ao STF (vide caput do art. 102), o Tribunal acumula dupla função institucional. As funções de Suprema Corte (isto é, tribunal de última instância recursal) e de Tribunal Constitucional (isto é, tribunal com a competência de fazer o controle de constitucionalidade de leis e atos normativos, seguindo a teoria kelseniana de controle de constitucionalidade).

O efeito disso é que o Pretório se vê assoberbado com o número de processos em relação ao número de Magistrados, ainda que se tenha criado o Superior Tribunal de Justiça pela Constituição Federal, com atribuições infraconstitucionais antes a cardo do STF.

Ao passo em que onze homens e mulheres ocupam as cadeiras do Supremo, no final de dezembro de 2016 no STF tramitavam 53.931 (cinquenta e três mil, novecentos e trinta e um processos), desde casos históricos, como a liberação para pesquisas em células tronco - vide ADI 3510 - até casos anedóticos como a decisão que manteve o clube de futebol Sport Club do Recife como campeão do campeonato brasileiro de 1987 (vide RE 881.864/DF). Mais que perplexão numérica, tais números contribuem para uma prestação jurisdicional deficitária no próprio conteúdo, além de obstaculizar a duração razoável do processo.

Ao equipar o Tribunal com atribuições desconexas a que uma Corte Constitucional guarda da Constituição, última palavra do controle de constitucionalidade, deveria ter, com matérias que claramente deveriam ficar a cargo do STJ ou de outro Tribunal a que se viesse a criar, verifica-se o comprometimento dos trabalhos do Pretório por uma anomalia do sistema. ${ }^{18}$

De se notar, no entanto, avanços em vista do desafogamento da corte em âmbitos constitucionais e infraconstitucionais posteriores ao Texto Magno de 88. A Emenda do Judiciário (EC $\mathrm{n}^{\circ} 45$ de 2004) foi a principal responsável pelas mudanças, já que a figura do

\footnotetext{
${ }^{18}$ A título argumentativo, cita-se o caso do R.E. 881.865/DF - que trata do título de campeão do campeonato brasileiro de futebol do ano de 1987, concedido ao Sport Clube Recife em decisão do STF.
} 
exequatur é hoje de atribuição do STJ; a necessidade de se provar a Repercussão Geral como pressuposto de admissibilidade recursal do Recurso Extraordinário; a criação do $\mathrm{CNJ}$; a instituição da Súmula Vinculante, dentre outras reformas no plano constitucional.

\section{CONCLUSÃO}

Não são poucos os pontos em que, nestes mais de 30 anos, a Constituição mostrou-se controvertida. Certamente, o fato de termos escolhido alguns desses não encerraria tal debate.

Em relação aos artigos não votados, pensamos, como dito alhures, que a ausência expressa da teoria da separação dos poderes não criaria maiores problemas para o intérprete maior da Constituição Federal, no caso o Supremo Tribunal Federal, uma vez que o texto constitucional acaba por adotar implicitamente referida teoria.

Por sua vez, no que concerne ao Artigo 166, §3º, Inciso II, alíneas "a", "b" e "c", do ponto de vista material de sua inclusão, não se apregoa aqui o assim chamado calote da dívida pública.

Além da possibilidade de controle por parte do Legislativo daquilo que o Executivo define como o valor dos gastos do governo a ser pago com o serviço da dívida, defende-se aqui que a Constituição possa constituir-a-ação por parte do legislador infraconstitucional, em prol de um dirigismo constitucional efetivo, não o seu modelo plutocrático da Constituição Dirigente Invertida (que privilegia o capital financeiro em prol dos direitos sociais, invertendo o sentido do dirigismo constitucional).

Caso contrário, a Constituição que propaga ser uma República constituída em Estado Democrático de Direito, que objetiva erradicar pobreza e marginalização e reduzir as desigualdades sociais e regionais, ficará sempre limitada por um Constitucionalismo voltado ao capital financeiro.

Quando aos Municípios, não há como conferir-lhes o caráter de ente federativo, na medida em que, muito embora atenda parte das características relacionadas à federação 
(descentralização político-administrativa e auto-organização), não preenche o predicado da participação das vontades parciais perante a vontade geral.

Segundo o texto constitucional presente no Artigo 46, somente os Estados e o Distrito Federal, via Senado Federal, podem participar da vontade nacional. Em outras palavras, podese dizer que tal poder não foi atribuído aos Municípios.

No que concerne à (im)possibilidade de participação popular através de emenda constitucional, importante realizar uma interpretação sistemática de nossa Constituição Federal, de forma a permitir que o povo tenha voz através das emendas constitucionais. Para tanto, necessário lembrar que inexiste previsão constitucional limitando ou cerceando os poderes do povo, tampouco é possível que o mandatário (membros do congresso nacional) restrinja ou cacem a competência do mandante (povo).

Por fim, no ponto relacionado ao Supremo Tribunal Federal, duas observações devem ser feitas.

A primeira está relacionada com a sua forma de composição, em especial, o modo de escolha dos Ministros, isto porque, com a alteração do art. 14, §5, $\mathrm{CF} / 88$, dada pela Emenda Constitucional $n^{\circ}$ 16/97, que instituiu, ainda no governo Fernando Henrique Cardoso, a figura da reeleição, criou-se a possibilidade de um Presidente da República indicar para o Supremo Tribunal Federal quase a totalidade dos ministros, como foi o caso do Presidente Luiz Inácio Lula da Silva (8), que juntamente com a Presidente Dilma Rousseff (5), chegou a indicar 13 integrantes.

O segundo aspecto está relacionado à competência, na medida em que não é aceitável que o Supremo Tribunal Federal, por exemplo, demore 42 anos para julgar uma ação de investigação de paternidade (para citar determinado processo que tramitou entre a primeira e a última instância por $63 \operatorname{anos}^{19}$ ), ação esta que sequer deveria se encontrar perante a Corte Maior, dada a matéria não constitucional e a importância de se vê-la apenas como guardiã da Constituição Federal.

\footnotetext{
${ }^{19} \mathrm{https} / /$ www1.folha.uol.com.br/mercado/2019/07/processo-leva-63-anos-para-ser-julgado-no-stf-e-ateadvogados-ja-morreram.shtml
} 


\section{REFERÊNCIAS}

BARROSO, Luís Roberto. Dez anos da Constituição de 1988 (foi bom para você também?). Revista Forense. 346:113, 1999.

Judicialização, ativismo judicial e legitimidade democrática. (Syn) thesis, v. 5, n. 1, p. 23-32, 2012.

BRANCO, Eduardo Lago Castello. Autonomia municipal e seus limites. Revista do instituto dos magistrados do Ceará, v. 23, p. 196-212, 2008.

BRASIL. Constituição da República Federativa do Brasil de 1988. Disponível em: <http://www.planalto.gov.br/ccivil_03/Constituicao/ConstituicaoCompilado.htm>. Acesso em: 04 out. 2017.

Emenda Constitucional no 26, de 27 de Novembro de 1985. Convoca Assembleia Nacional Constituinte e dá outras providências. Disponível em: $<$ http://www.planalto.gov.br/ccivil_03/Constituicao/Emendas/Emc_anterior1988/emc2685.htm.htm. Acesso em 20 abr. 2017>.

CASTRO, José Nilo de. Direito municipal positivo. 7. ed. Belo Horizonte: Del Rey, 2010.

CAVALCANTI, Tatiane Heloisa Martins. O município na organização político-administrativa da República Federativa do Brasil. Revista eletrônica direito e política, Itajaí, v.2, n.3, $3^{\circ}$ quadrimestre de 2007. Disponível em: www.univali.br/direitoepolitica - ISSN 1980-7791.

FERREIRA FILHO, Manoel Gonçalves. O poder constituinte. 6. ed. São Paulo: Saraiva, 2014.

HABERMAS, Jürgen. A inclusão do outro: estudos de teoria política. São Paulo: Edições Loyola, 2012.

MARTÍNEZ-VARGAS, Ivan. Processo leva 63 anos para ser julgado no STF, e até advogados já morreram. Folha de São Paulo. 21 de julho de 2019. Disponível em: $<$ https://www1.folha.uol.com.br/mercado/2019/07/processo-leva-63-anos-para-ser-julgadono-stf-e-ate-advogados-ja-morreram.shtml>. Acesso em 21 jan. 2020.

MASSONETTO, Fernand; BERCOVICI, Gilberto. A Constituição Dirigente Invertida: a blindagem da Constituição Financeira e a Agonia da Constituição Econômica. Boletim de Ciências Econômicas XLIX, págs. 2/23. Coimbra: Universidade de Coimbra, 2006.

MEDEIROS, Lydia. Artigos da Constituição Federal de 88 entraram em vigor sem votação. O GLOBO. 05 de outubro de 2003. Disponível em: <http://memoria.oglobo.globo.com/jornalismo/edicoes-especiais/sem-votaccedilatildeo9938719>. Acesso em: 21 jan. 2020.

MEIRELLES, Hely Lopes Meirelles. Direito municipal brasileiro. 16. ed. São Paulo: Malheiros Editora, 2006. 
MENDES, Gilmar; BRANCO, Paulo Gonet, COELHO, Inocêncio Martins. Curso de direito constitucional. 2. ed. São Paulo: Saraiva, 2008.

MENDES, Gilmar Ferreira; BRANCO, Paulo Gonet. Curso de direito constitucional. 10. ed. São Paulo: Saraiva, 2015.

MOREIRA, José Carlos Barbosa. O Poder Judiciário e a efetividade da nova Constituição. In: Revista Forense: edição comemorativa de 100 anos. p. 763-771. Rio de Janeiro: Forense, 2005

RESENDE, Pedro Antônio Dourado de; BENAYON, Adriano. Anatomia de uma fraude à Constituição. Agosto de 2006, departamento de ciência da computação da Universidade de Brasília. Disponível em: <http://cic.unb.br/ pedro/trabs/fraudeac_files/fraudeac.pdf>. Acesso em: 06 out. 2017.

SIEYÈS, Emmanuel-Joseph. A constituinte burguesa: que é o terceiro Estado? Rio de Janeiro: Liber Juris, 1988.

SILVA, José Afonso da. Curso de direito constitucional positivo. 32. ed. São Paulo: Malheiros, 2009.

Poder constituinte e poder popular: estudos sobre a Constituição. 1. ed. São Paulo: Malheiros, 2007.

SILVA, Paulo Vitor Nunes da. A Luta por reconhecimento no Estado Democrático de Direito de movimentos emancipatórios no pensamento de Jürgen Habermas. Revista São Luís Orione., v.1, 1. ed. ArTaguaína: Facdo, 2015.

SOUZA NETO, Cláudio Pereira de; SARMENTO, Daniel. Direito constitucional: teoria e métodos de trabalho. 1. ed. Belo Horizonte: Fórum, 2012. 1.233 KB: e-pub Produção da versão eletrônica: 2012

VILAÇA, Marcos Vinicios; ALBUQUERQUE, Roberto Cavalcanti de. Coronel: coronéis apogeu e declínio do coronelismo no Nordeste. Rio de Janeiro: Bertrand Brasil, 2003.

Data de Submissão: 11/05/2020

Data de Aceite: $30 / 05 / 2020$ 